\title{
Hemato-biochemical and therapeutic studies on Escherichia coli associated with concurrent enteric infection in lambs
}

\author{
Nuzhat Hassan ${ }^{1}$, G. N. Sheikh ${ }^{1}$, H. U. Malik ${ }^{1}$, M. Shaheen ${ }^{1}$ and M. M. Willayat ${ }^{2}$ \\ 1. Department of Veterinary Medicine, Faculty of Veterinary Sciences, Sher-e-Kashmir University of \\ Agricultural Sciences \& Technology-Kashmir, Shuhama Campus, Srinagar- 190 006, J \&K, India; \\ 2. Department of Veterinary Public Health, Sher-e-Kashmir University of Agricultural Sciences \& \\ Technology-Kashmir, Shuhama Campus, Srinagar- 190 006, J\&K, India \\ Corresponding author: Nuzhat Hassan, email: drnuzhatzargar@gmail.com \\ Received: 09-07-2013, Revised: 19-08-2013, Accepted: 20-08-2013, Published online: 05-10-2013
}

doi: $10.14202 /$ vetworld.2013.870-873

How to cite this article: Hassan N, Sheikh GN, Shaheen M and Willayat MM (2013) Hemato-biochemical and therapeutic studies on Escherichia coli associated with concurrent enteric infection in lambs, Veterinary World 6(11): 870-873.

\begin{abstract}
Aim: The trials were designed on 30 lambs of age below 2 weeks exhibiting the symptoms of colibacillosis.

Materials and Methods: Isolation of organism and identification of pathogenic Escherichia coli was confirmed by standard cultural, microbiological, serological, and biochemical tests. Venous blood was collected aseptically for hematological studies.

Result: Bacteriological examinations of fecal sample were positive for E.coli and isolates identified on the basis of morphological, cultural, and biochemical characteristics provided further confirmation. Hematological indices recorded significant $(\mathrm{p}>0.05)$ increase in the packed cell volume, total leucocyte count, lymphocyte, and neutrophil percentage, whereas biochemical indices recorded significant decrease in the serum glucose, protein and serum albumin/globulin levels. Treatment regimen in four different groups, suggested, gentamicin and ciprofloxacin effective drugs followed by neomycin and co-trimoxazole.
\end{abstract}

Conclusion: Study suggested significant $(\mathrm{P}>0.05)$ alteration in hemato-biochemical parameters whereas results indicated gentamicin and ciprofloxacin as most effective drugs.

Keywords: enteric infection, Escherichia coli, hemato-biochemical, lambs

\section{I ntroduction}

The success of sheep farming is largely based on the good health status and low mortality rate during earlier life. This is measured in terms of lambs successfully reared in a given season which can be achieved by decreasing early mortality rate over a shorter period of time [1]. Epidemiological studies on diarrhoea in lambs have shown that Escherichia coli is an important cause of neonatal mortality [2, 3]. Colibacillosis is one of the important diseases in farm animals caused by pathogenic serotypes of E. coli [4]. Escherichia coli has been associated with two forms of infections; enteric and septicemic infection. - The enteric form is more commonly observed in 2 to 8 day old lambs, and characterized by varying degree of diarrhoea, dehydration, and huge mortality in untreated cases. The E.coli infection has been reported to be associated with diarrhea in neonate farm animals [5]. The pathophysiology of colibacillosis is due to K99+ adhesin antigen and heat stable enterotoxin, the major virulence attributes of enteric strain of E.coli in farm ruminants $[6,7]$. It is a significant cause of economic loss in raising sheep and one of the important zoonotic diseases [8, 9]. In the present investigation, a detailed

Copyright: The authors. This article is an open access article licensed under the terms of the Creative Commons Attribution License (http://creativecommons.org/licenses/by/2.0) which permits unrestricted use, distribution and reproduction in any medium, provided the work is properly cited. study of hemato-biochemical parameters of diarrheic lambs with pathogenic E.coli isolated and evaluation of different therapeutic regimens for treatment of colibacillosis was undertaken.

\section{Materials and Methods}

Ethical approval: Study was performed according to the 'Guidelines for Animal Experimentation' approved by the Institutional Animal Care Committee.

The clinical trials were designed on thirty lambs exhibiting the symptoms of diarrhea, dehydration, fever, and anorexia. These animals were divided into five groups (six animals each). Rectal swabs were collected aseptically for the confirmation and $i$ dentification of pathogenic $E$. coli by standard cultural, microbiological, serological and biochemical tests [10]. Four drug regimens were used in four groups which included four different antibacterial (Ciprofloxacingroup II, Co-trimoxazole-group-III, Gentamicingroup-IV, Neomycin-group-V), whereas group-I of six healthy lambs was kept as healthy control group. Only those antibacterial were used which showed moderate to high in-vitro sensitivity against $E$. coli isolates, which were readily available and economically feasible. For hematological studies blood was collected from each animal of all groups in clean sterilized glass vials containing EDTA, as anticoagulant. For separation of serum $10 \mathrm{ml}$ of blood was collected in sterile centrifuge tubes and kept in slanting position for about an hour at 
Table-1. Hematobiochemical values (Mean \pm SE) before and after treatment

\begin{tabular}{|c|c|c|c|c|c|c|}
\hline Groups & Healthy & $\begin{array}{l}\text { Infected and } \\
\text { untreated }\end{array}$ & Ciprofloxacin & Co-trimoxazole & Gentamicin & Neomycin \\
\hline \multicolumn{7}{|l|}{$\mathbf{H b}$} \\
\hline 0 day & $12.45 \pm 0.47^{\mathrm{aA}}$ & $11.98 \pm 0.43^{\mathrm{abAB}}$ & $11.37 \pm 0.35^{\mathrm{abBC}}$ & $11.70 \pm 0.32^{\mathrm{bBC}}$ & $11.73 \pm 0.36^{\mathrm{abA}}$ & $13.42 \pm 0.57^{\mathrm{aA}}$ \\
\hline 6 day & $12.62 \pm 0.33^{\mathrm{aAB}}$ & $11.03 \pm 0.32^{\mathrm{bBC}}$ & $11.70 \pm 0.55^{\mathrm{abBC}}$ & $11.790 \pm 0.55^{\mathrm{abBC}}$ & $11.17 \pm 0.33^{\mathrm{bc}}$ & $12.45 \pm 0.51^{\mathrm{abAB}}$ \\
\hline \multicolumn{7}{|l|}{ PCV } \\
\hline 0 day & $36.75 \pm 0.60^{\mathrm{aA}}$ & $40.30 \pm 1.92^{\mathrm{aAB}}$ & $41.33 \pm 1.77^{\mathrm{aBC}}$ & $34.24 \pm 1.73^{\mathrm{cA}}$ & $43.17 \pm 1.42^{\mathrm{bcB}}$ & $39.00 \pm 1.34^{\mathrm{abA}}$ \\
\hline \multicolumn{7}{|c|}{ 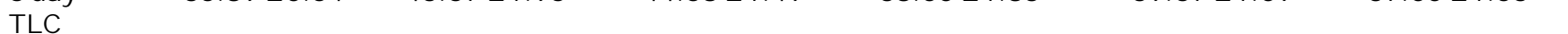 } \\
\hline 0 day & $5.41 \pm 0.91^{\mathrm{abA}}$ & $7.13 \pm 0.23^{\mathrm{aBC}}$ & $6.68 \pm 0.18^{\mathrm{CBC}}$ & $6.20 \pm 0.25^{\mathrm{CAC}}$ & $6.62 \pm 0.26^{\mathrm{CBC}}$ & $5.79 \pm 0.29^{\mathrm{cA}}$ \\
\hline \multicolumn{7}{|c|}{ Neutrophills } \\
\hline 0 day & $25.66 \pm 0.67^{\mathrm{aABC}}$ & $26.16 \pm 1.10^{\mathrm{aBC}}$ & $20.00 \pm 1.39^{\mathrm{bB}}$ & $22.83 \pm 1.35^{\mathrm{CAB}}$ & $25.67 \pm 0.80^{\mathrm{bA}}$ & $24.83 \pm 1.54^{\mathrm{abAB}}$ \\
\hline 6 day & $26.50 \pm 0.99^{\mathrm{aA}}$ & $26.00 \pm 1.36^{\mathrm{aA}}$ & $22.83 \pm 1.08^{\mathrm{bA}}$ & $25.67 \pm 0.56^{\mathrm{bABC}}$ & $25.00 \pm 0.68^{\mathrm{abc}}$ & $21.67 \pm 1.63^{\mathrm{bB}}$ \\
\hline \multicolumn{7}{|c|}{ Lymphocytes } \\
\hline 0 day & $49.16 \pm 0.48^{\mathrm{bCA}}$ & $69.33 \pm 2.62^{\mathrm{aB}}$ & $54.83 \pm 1.38^{\mathrm{aC}}$ & $53.83 \pm 1.33^{\mathrm{aC}}$ & $57.17 \pm 1.60^{\mathrm{aC}}$ & $60.33 \pm 3.25^{\mathrm{ac}}$ \\
\hline $\begin{array}{l}6 \text { day } \\
\text { TEC }\end{array}$ & $50.17 \pm 0.48^{\mathrm{cA}}$ & $65.67 \pm 3.02^{\mathrm{abB}}$ & $47.00 \pm 1.24^{\mathrm{bA}}$ & $50.33 \pm 0.67^{\mathrm{bA}}$ & $49.17 \pm 0.61^{\mathrm{bA}}$ & $50.00 \pm 1.59^{\mathrm{bA}}$ \\
\hline 0 day & $5.38 \pm 0.18^{\mathrm{aB}}$ & $7.10 \pm 0.36^{\mathrm{aA}}$ & $5.90 \pm 0.28^{\mathrm{bC}}$ & $6.53 \pm 0.21^{\mathrm{bCB}}$ & $6.56 \pm 0.31^{\mathrm{bCB}}$ & $6.29 \pm 0.22^{\mathrm{ac}}$ \\
\hline 6 day & $6.69 \pm 0.20^{\mathrm{aB}}$ & $7.55 \pm 0.19^{\mathrm{aA}}$ & $6.68 \pm 0.35^{\mathrm{aA}}$ & $7.26 \pm 0.35^{\mathrm{aA}}$ & $7.44 \pm 0.31^{\mathrm{aA}}$ & $6.20 \pm 0.24^{\mathrm{bCB}}$ \\
\hline \multicolumn{7}{|c|}{ Blood glucose } \\
\hline 0 day & $78.49 \pm 2.39^{\mathrm{aA}}$ & $46.34 \pm 1.65^{\mathrm{aB}}$ & $56.16 \pm 2.62^{\mathrm{aB}}$ & $52.8 \pm 3.52^{\mathrm{aB}}$ & $51.17 \pm 2.85^{\mathrm{aB}}$ & $64.07 \pm 2.96^{\mathrm{abc}}$ \\
\hline $\begin{array}{l}6 \text { day } \\
\text { Serum p }\end{array}$ & $81.45 \pm 2.20^{\mathrm{aA}}$ & $51.00 \pm 1.29^{\mathrm{aB}}$ & $73.31 \pm 3.37^{\mathrm{bA}}$ & $77.57 \pm 5.07^{\mathrm{CA}}$ & $77.55 \pm 4.58^{\mathrm{cA}}$ & $80.87 \pm 2.71^{\mathrm{CA}}$ \\
\hline 0 day & $8.09 \pm 0.16^{\mathrm{aA}}$ & $5.12 \pm 0.24^{\mathrm{aB}}$ & $5.57 \pm 0.33^{\mathrm{aB}}$ & $5.81 \pm 0.34^{\mathrm{aB}}$ & $5.12 \pm 0.29^{\mathrm{aB}}$ & $5.41 \pm 0.28^{\mathrm{aB}}$ \\
\hline $\begin{array}{l}6 \text { day } \\
\text { Albumin }\end{array}$ & $7.99 \pm 0.33^{\mathrm{aA}}$ & $5.39 \pm 0.34^{\text {ав }}$ & $6.96 \pm 0.29^{b c}$ & $8.28 \pm 0.21^{C D}$ & $7.30 \pm 0.47^{\mathrm{CAC}}$ & $8.37 \pm 0.22^{C D}$ \\
\hline 0 day & $3.11 \pm 0.19^{\mathrm{aA}}$ & $1.89 \pm 0.19^{\mathrm{aB}}$ & $1.92 \pm 0.22^{\mathrm{aB}}$ & $2.61 \pm 0.34^{\mathrm{aA}}$ & $2.09 \pm 0.16^{\mathrm{aB}}$ & $2.36 \pm 0.22^{\mathrm{aB}}$ \\
\hline $\begin{array}{l}6 \text { day } \\
\text { Globulin }\end{array}$ & $2.96 \pm 0.19^{\mathrm{aA}}$ & $2.44 \pm 0.22^{\mathrm{aAB}}$ & $3.13 \pm 0.10^{\mathrm{CA}}$ & $3.38 \pm 0.22^{\mathrm{aA}}$ & $3.30 \pm 0.16^{\mathrm{CA}}$ & $3.65 \pm 0.09^{c A}$ \\
\hline 0 day & $4.81 \pm 0.24^{\mathrm{aA}}$ & $3.37 \pm 0.28^{\mathrm{aB}}$ & $3.55 \pm 0.13^{\mathrm{aB}}$ & $4.16 \pm 0.20^{\mathrm{bB}}$ & $3.65 \pm 0.22^{\mathrm{abB}}$ & $4.02 \pm 0.40^{\mathrm{abB}}$ \\
\hline 6 day & $5.05 \pm 0.19^{\mathrm{aA}}$ & $2.95 \pm 0.47^{\mathrm{aB}}$ & $3.83 \pm 0.34^{\mathrm{ac}}$ & $4.90 \pm 0.25^{\mathrm{CA}}$ & $4.00 \pm 0.32^{\mathrm{bCA}}$ & $4.72 \pm 0.29^{\mathrm{bA}}$ \\
\hline
\end{tabular}

Values with Similar superscript (Capital letters-Between groups and small letters - Within groups) do not differ significantly $(P>0.05)$

room temperature. The blood clot was broken and subsequently centrifuged at $2000 \mathrm{rpm}$ for 30 minutes. $\mathrm{Hb}, \mathrm{PCV}$, TLC and TEC were determined using standard procedures as described by [11]. Glucose was estimated by Trinder method [12] and total protein/albumin was determined by Doumas method [13] (Kits supplied: Coral-Clinical System, Crest Biosystems, Goa, India).

Statistical analysis: The results were subjected to statistical analysis as per the ANOVA method [14].

\section{Results}

Detailed clinical observations were recorded in all lambs which presented variable clinical symptoms of disease like scant fecal volume to profuse waterywhitish diarrhoea, soiling of perineum and tail, mild to moderate dehydration, rough body coat, dry mouth/muzzle, profound weakness, and slight increase in temperature. In all the groups of lambs with clinical colibacillosis, nonsignificant increase in the values of hemoglobin was recorded. There was significant increase in packed cell volume, total leukocyte count, lymphocyte count, and neutrophil percentage (Table-1). Serum glucose, protein and serum albumin/ globulin value showed declining trend in infected lambs as compared to healthy lambs. In case of treatment groups significant increase was seen in serum glucose, protein and serum albumin/ globulin value after $6^{\text {th }}$ day post treatment.

In the present study, the treatment of the clinical cases of colibacillosis in lambs was studied on four trail groups of six lambs each. In these trail groups, therapeutic efficacy of four different antibacterial viz. Ciprofloxacin, Gentamicin, Neomycin, and Cotrimoxazole was evaluated (which showed higher in vitro sensitivity against $E$. coli isolates) against clinical colibacillosis in lambs. In gentamicin and neomycin treated group, the hemoglobin value showed decreasing trend and by day $6^{\text {th }}$ post treatment, there was significant $(\mathrm{P}>0.05)$ decrease as compared to values at ' 0 ' day. In ciprofloxacin and co-trimoxazole treated groups progressive decrease was observed in hemoglobin value that was not-significant $(\mathrm{P}>0.05)$ at $6^{\text {th }}$ day post treatment as compared to 0 day. In ciprofloxacin, co-trimoxazole, gentamicin and neomycin treated groups there was significant $(\mathrm{P}>$ $0.05)$ increase in total erythrocyte count at 144 hours post treatment $\left(6^{\text {th }}\right.$ day $)$. In all infected groups, the mean total leucocyte count was significantly $(\mathrm{P}>0.05)$ higher. However, the total leucocyte count was nonsignificantly lower in case of ciprofloxacin and gentamicin treated groups but significantly lower in case of co-trimoxazole and neomycin treated groups as compared to values of infected untreated control, whereas, values in treatment groups were comparable to healthy control by $6^{\text {th }}$ day post treatment. 
Table-2. Therapeutic trials in clinical cases of colibacillosis in lambs

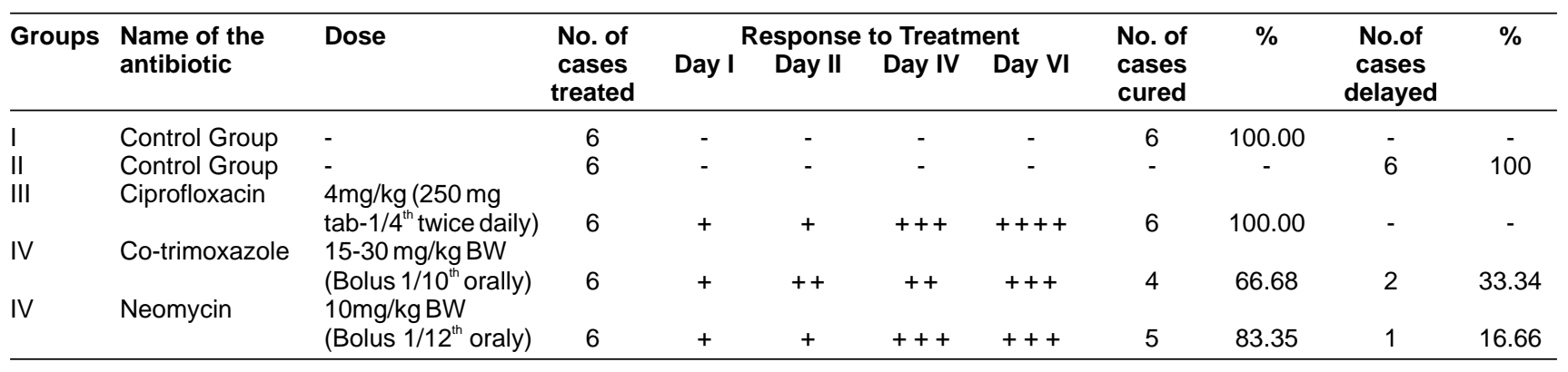

$+=$ Slightly improved; $++=$ Improved; $+++=$ Recovery; $++++=$ Complete recovery

The neutrophil values were significantly $(\mathrm{P}>$ $0.05)$ lower in ciprofloxacin and neomycin treated, however, non-significantly lower in co-trimoxazole and gentamicin treated groups as compared to both infected untreated group and healthy control at 144 hours post treatment. By day $6^{\text {th }}(144 \mathrm{hrs})$ there was significant $(\mathrm{P}>0.05)$ decrease in the lymphocyte percentage in different treated groups and compared to infected untreated control, but comparable to healthy control group. By day $6^{\text {th }}$ (144 hours), the blood glucose levels recorded in treated groups were significantly $(\mathrm{P}$ $>0.05$ ) higher as compared to infected untreated control but were comparable to healthy control. The protein levels were significantly higher in cotrimoxazole and neomycin treated groups as compared to infected untreated group and comparable to healthy control at 96 hours post treatment. In gentamicin treated group, the protein values were comparable to healthy control only at 144 hours post treatment. By day $6^{\text {th }}(144 \mathrm{hrs})$ albumin levels in different infected groups were comparably similar to healthy control. The globulin levels recorded by day $6^{\text {th }}$ (144 hours) in gentamicin and neomycin treated groups respectively, which were significantly higher as compared to their respective values on zero day. These values were also comparable to healthy control group.

The therapeutic efficacy of four highly sensitive in vitro drugs was evaluated viz. gentamicin, ciprofloxacin, neomycin and co-trimoxazole. Gentamicin at the dose rate of $4 \mathrm{mg} / \mathrm{kg}$ body weight and Ciprofloxacin at the dose rate of $4 \mathrm{mg} / \mathrm{kg}$ body weight were found 100 per cent effective at 144 hour post treatment. Neomycin at the dose rate of $10 \mathrm{mg} / \mathrm{kg}$ body weight was 83.35 per cent effective and cotrimoxazole at the dose rate of $15-30 \mathrm{mg} / \mathrm{kg}$ body weight was 66.8 per cent effective at 144 hour post treatment. Treatment regimen used in four different groups of clinical cases of colibacillosis indicated gentamicin and ciprofloxacin most effective drugs followed by neomycin and co-trimoxazole which was comparable with in vitro study.

In ciprofloxacin and gentamicin treated groups the rate of recovery $(+)$ during $1^{\text {st }}$ day of treatment was obvious with decrease in dehydration and capillary refill time whereas, there was increase recorded in blood glucose and protein levels post treatment. However by day $6^{\text {th }}$ (144 Hours) rate of recovery was complete $(++++)$ as compared to day $3^{\text {rd }}(+++)$ and hematobiochemical indices were comparable to healthy control. Lambs treated with oral cotrimoxazole showed delay in recovery and on $3^{\text {rd }}$ day rate of recovery $(++)$ in four cases was recorded with normalizing clinical symptoms. However by day $6^{\text {th }}(+$ ++ ) all four lambs recovered $(66.68 \%)$ with delay of clinical recovery in two cases. In neomycin treated group, rate of recovery was evident during $1^{\text {st }}(+)$ and $3^{\text {rd }}$ $(+++)$ day with dehydration status returning to normal and obvious increase in blood glucose and protein levels. By day $6^{\text {th }}$ five animals $(83.35 \%)$ completely recovered $(+++)$ with a delay in one case (Table- 2 ).

\section{Discussion}

Increase in haemoglobin values in diarrhoeic lambs might be due to hemoconcentration confirming the fluid loss from vascular compartment [15]. Nonsignificant increase in the values of hemoglobin was recorded [16, 17]. Significant increase in packed cell volume, total leucocyte count, lymphocyte count and neutrophil percentage indicated the presence of intestinal infection $[18,19,20]$. Declining trend of serum glucose, protein, and serum albumin in infected lambs as compared to healthy lambs were reported in diarrhoeic kids [21]; similar findings were reported in scouring calves compared to healthy calves $[22,23$, 24]. The drugs helped in normalizing the hematobiochemical changes like hemoglobin, packed cell volume, total leucocyte count, blood glucose and total protein.

The efficacy of the drugs was assessed as per the rate and degree of recovery of clinical symptoms. Gentamicin at the dose rate of $4 \mathrm{mg} / \mathrm{kg}$ body weight $(0.3 \mathrm{ml} \mathrm{i} / \mathrm{m}$ bid $)$ and Ciprofloxacin at the dose rate of 4 $\mathrm{mg} / \mathrm{kg}$ body weight orally $\left(250 \mathrm{mg}\right.$ tab- $1 / 4^{\text {th }}$ twice daily) daily for five days proved to be most effective drugs wherein, drugs helped in restoration of the disturbed haematobiochemical changes and abating clinical symptoms. The drugs helped in normalizing the haemato-biochemical changes like hemoglobin, packed cell volume, total leucocyte count, blood glucose and total protein. These drugs showed good results and have been 100 per cent effective for treating enteric colibacillosis. Other group of lambs was treated with another conventional gut acting antibacterial Neomycin at the dose rate of $10 \mathrm{mg} / \mathrm{kg}$ body weight 
orally for five days. Five of the lambs clinically responded well with the fecal consistency returning to normal within six days. There was however, a significant increase in the total glucose, total protein and albumin fraction with restoration of hematological values post treatment in the neomycin treated group within six days which suggest that drug was effective for treating colibacillosis. The infected group of lambs treated with Co-trimoxazole at the dose rate of 15-30 $\mathrm{mg} / \mathrm{kg}$ body weight orally $\left(1 / 10^{\text {th }}\right.$ bolus $)$. There was marked improvement in clinical signs in four cases by day six with delay in recovery in two cases even after 144 hour post treatment. These antibiotics help in restoration of disturbed hematobiochemical parameters towards normalcy by day six. Similar efficacy against $E$. coli diarrhea was reported by [25]. As per the present study the clinical cases of colibacillosis in lambs were effectively treated by gentamicin and ciprofloxacin followed by neomycin and co-trimoxazole.

\section{Conclusion}

Our study indicated significant alterations in hemato-biochemical parameters with significant increase in packed cell volume, total leukocyte count, lymphocyte count, and neutrophil percentage pretreatment with significant decrease post-treatment. This was due to the treatment regimen used in four different groups of clinical cases of colibacillosis, which suggested gentamicin and ciprofloxacin as most effective drugs followed by neomycin and cotrimoxazole that was comparable to in vitro study.

\section{Authors' contributions}

NH, GNS, MMW designed and planned the experiment. The experiment and case study was done by $\mathrm{NH}$ and GNS. GNS, HUM and MS revised the final draft of experiment. All the authors interpreted the results, read and finally the manuscript was approved by all after thorough and careful considerations.

\section{Acknowledgments}

The authors would like to thank the Department of Veterinary Medicine and Sheep Research Station Shuhama, SKUAST-K for providing full assistance and support for the research work. The authors are thankful to Postgraduate study unit, SKUAST-K for providing fund for this study.

\section{Competing interests}

The authors declare that they have no competing interests.

\section{References}

1. Vihan, V.S., Joshi, J.D. and Sahni, K.L. (1982) Studies on various factors affecting lamb $E$. coli isolated from diarrhoeic buffalo and cow calves. Indian J of Microbiol, 32: 69-73.

2. Ahmed, A. (2009) Epidemiological studies on some causes of lamb mortality in Sokoto state. PhD. Thesis. Usmanu Danfodiyo University, Sokoto, Nigeria.

3. Ok, M..L., Guler, K., Turgut, U. and Guzelbektes, H. (2009)
The studies on the aetiology of diarrhoea in neonatal calves and determination of virulence gene markers of Escherichia coli strains by Multiplex PCR. Zoonoses Public Health, 56: 94-101.

4. Gyles, C.L. (1994) E. coli in domestic animals and Humans. Wallingford, UK: CAD.

5. Gokce, E., Unver, A. and Erdogan, H.M. (2010) Enteric pathogens in the aetiology of diarrhoea in neonatal lambs. Kafkas Universitesi Veteriner Fakultesi Dergisi 16 (5): 717 722.

6. Hossian, M.M., Saha, S., Samad, M.A. and Choudhury, K.A. (2002) Isolation and characterization of Enterobacteria from diarrheic calves with their pathogenicity in mice and in-vitro sensitivity to antibiotics. Bangladesh Vet J, 3643-49.

7. Nguyen, T.D., Vo, T.T. and Vu-Khac, H. (2011) Virulence factors in Escherichia coli isolated from calves with diarrhea in Vietnam. J. Vet. Sci. 12: 159-164.

8. Borgattaa, B., Kmet, N. and Relloc, J. (2012). E. Coli O104:H4 outbreak and haemolytic - uraemic syndrome. Med. Intensiva. doi: 10.1016/j.medin.2011.11.022.

9. Beutin, L. and Martin, A. (2012) Outbreak of shiga toxinproducing Escherichia coli (STEC) O104:H4 infection in Germany causes a paradigm shift with regard to human pathogenicity of STEC strains. J. Food Prot, 75: 408-418.

10. Barrow, G. I. and Felham, R.K.A. (1992) Cowan and steel's Manual for the identification of Medical Bacteria. II Edn. University Press, Cambridge.

11. Schalm, O.W. (1986) Veterinary Hematology. III edition Lea and Febiger. Philadelphia, USA: Saunders.

12. Trinder, P. (1969) Glucose estimation. Annual Clin Biochem, 6: 24.

13. Doumas, B.J. (1970) Protein estimation. Cli Chemistry, 21: 1159.

14. Snedecor, C.S. and Cochran, W.G. (1994) Statistical methods. $8^{\text {th }}$ Ed., USA: The Iowa State University Press, Ames.

15. Radostits, O.M., Gay, C.C., Blood, D.C. and Hinchcliff, K.W. (2000) Veterinary Medicine. IX Edition. W.B. Saunders, pp. 1499.

16. Kumar, R., Mandial, R.K. and Gupta, N. (2002) Clinicobiochemical and therapeutic studies on clinical colibacillosis in cross bred calves. Indian J Vet Med, 22(1): $1-3$.

17. Das, R.K., Mahato, Dutta, G. and Barman, N.N. (2008) Haemato-biochemical changes in piglet diarrhea associated with $E$. coli and rotavirus infection and its therapeutic management. Indian J Vet Med, 28(1): 9-12.

18. Tikoo, A. and Soodan, J.S. (2009) Colibacillosis in neonatal calves and its management. Intas Polivet, 10: 212-13.

19. Radostits, O.M., Gay, C.C., Hinchcliff, K., Constable, P.D. (2007) Veterinary Medicine. A Textbook of the Diseases of Cattle, Horses, Sheep, Pigs, and Goats, 10th edn. Saunders Elsevier, Philadelphia.

20. Sridhar, P.S.P. and Rakesh, K. (1988) Clinical and pathological alteration in calf scour. Indian Vet J, 63: 771774.

21. Radhakishan, Y., Rao, R., Gaffar, A.A. and Reddy, R.M. (1991) Haematological and biochemical studies on neonatal diarrhoeic buffalo calves. Indian J Vet Med, 11(1,2): 34 .

22. Roy, S., Sinh, R.P. and Prasad, R.S. (1984). Evaluation of oral fluids treatment of diarrhea in kids. Indian Vet J, 61: 94652.

23. Daliwal, P.S. (1993) Studies on fluid and electrolyte balance in buffalo calves with special reference to its therapy. Ph.D. Dissertation, Punjab Agricultural University, Ludhiana.

24. Deshpande, A.P., Anantwar, L.G., Digraskar, S.U. and Deshpande, A.R. (1993) Clinicopathological and biochemical alterations in calf scour. Indian Vet J, 70: 679680.

25. Sakia, T. and Harashima, M. (1985) Therapeutic of Triminol Powder (TA-068) in colibacillosis diarrhea in piglet. J Japan Vet MedAssoc, 38(1). : 93-97. $* * * * * * * *$ 